\title{
Adana’da Bir İnşaat Firmasında İş Kazalarının ve Çalışma Koşulları ile İlişkisinin Değerlendirilmesi
}

Research of the Relationship Between Occupational Accidents and Working Conditions of Workers of a Construction Company in Adana

\author{
Emine Ateș ${ }^{1}$, Necdet Aytaç ${ }^{2}$ \\ ${ }^{1}$ Silopi İlçe Sağlık Müdürlüğü, Şırnak \\ ${ }^{2}$ Sanko Üniversitesi, Tip Fakültesi, Halk Sağğğg Anabilim Dalı, Gaziantep
}

Yazışma Adresi / Correspondence:

Emine Ateş

Dicle Mah. 25. Cad. 1004.Sk. Eski Hastane Binası, No: 54 Silopi/Şırnak

T: +90506 4077059 E-mail : dr.emineyener@gmail.com

Geliş Tarihi / Received : 02.07.2019 Kabul Tarihi / Accepted : 04.12.2019

Orcid :

Emine Ateş https://orcid.org/: 0000-0002-3179-1883

Necdet Aytaç https://orcid.org/0000-0002-2560-2783

( Sakarya Tip Dergisi / Sakarya Med J 2019, 9(4):661-668 ) DOI: 10.31832/smj.585769

3. Uluslararası Mesleksel ve Çevresel Hastalıklar Kongresi’nde (3-7 Mart 2019,Antalya) sözlü sunum olarak sunulmuștur.

\footnotetext{
Öz

Amaç Çalışma ortamından kaynaklı olumsuz koşullar iş kazalarına neden olmaktadır. Bu çalışmanın amacı, Adana’da bir inşaat firmasında çalışanların iş kazaları ve iş kazalarının çalışma koşullarıyla ilişkisinin araştırılmasıdır.

Gereç ve Kesitsel tipteki bu araștırma 2017 yllı Haziran-Aralık tarihleri arasında Adana’daki bir inşaat şirketinde çalışan 326 kişiye uygulandı. Veriler 49 soruluk bir anket formu Yöntemler kullanılarak SPSS 20 programı ile değerlendirildi.

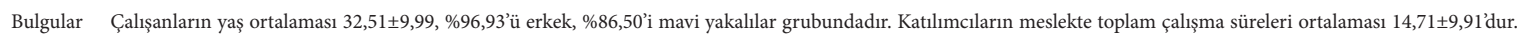
Çalıșanların \%97,2'sinin haftalık çalıșma saati 45 saat üzeri olarak belirlendi. Katılımcıların \%23,31'i çalıștıkları ișten, \%38,95’i çalıșma saatinden memnun değildi. İșini stresli olduğunu düsünen \%71,16, ișinin sağlığına zarar verdiğini düșünen ise \%52,76’sı idi. Katılımcıların \%28,8'i kișisel koruyucu donanım kullanmadığını belirtti. Katılımcıların \%5,21’si bu işyerinde, \%16,87’si çalışma hayatı boyunca iş kazası geçirmişti. Kazalar en sık yüksekten düşme, hafta başı ve sonunda, yaz ve kıș mevsimle-rinde ve ilk iki saatte olmuştur. İş kazası geçirme durumu ile sigara içme durumu arasında anlamlı fark vardı(p<0,05).

Sonuç İș kazası geçirme sıklı̆ı \%5,2 idi. Sigara içenlerde iş kazası anlamlı olarak yüksek bulunmuștur. İș kazalarını önlemek için gerekli koruyucu önlemler alınmalı, iş sağlı̆̆ı ve güvenliği ve sigara bağımlılığına yönelik eğitimler verilmelidir.

Anahtar inşaat; iş kazası; çalışma hayatı

kelimeler

Abstract

Objective Negative conditions originating from the working environment cause occupational accidents. The aim of this study is to research occupational accidents and the relationship between occupational accidents and working conditions of employees working in a construction company in Adana.

Materials This cross-sectional study was conducted on 326 individuals from a construction company in Adana between June and December 2017. The data were evaluated with SPSS 20 program using and Methods a 49 questions questionnaire.

Results The mean age of the employees was $32,51 \pm 9,99,96,93 \%$ was male, $86,50 \%$ are in the blue collar group. The average working time of the participants was $14,71 \pm 9,91$ years. $97,20 \%$ of employees had weekly working hours of over 45 hours. $23,31 \%$ of the participants were not satisfied with their work, 38,95\% were not satisfied with their working hours. It was $71,16 \%$ who thought his job was stressful, 52.76\% of the employees think that they harm the health of their work. $28,80 \%$ of the participants said that they did not used personal protective equipment. 5,21\% of the parti-cipants in this work place, $16.87 \%$ of them had a work accident during their working lives. Accidents most often falls fromheights, beginning and end of the week, summer and winter seasons and became the first two hours. There was difference between occupational accident and smoking $(p<0,05)$.

Conclusion The frequency of occupational accidents was $5.21 \%$. Occupational accidents were significantly higher among smokers. To prevent occupational accidents; necessary protective measures should be taken, occupational health and safety training and smoking addiction should be provided.

Key words construction; work accident; work life
} 


\section{GIIRIș}

İş kazası belirli bir hasara ya da bedensel yaralanmaya yol açan, birden ortaya çıkan ve planlanmamış bir olay olarak tanımlanmaktadır. ${ }^{1}$ İş kazaları, iş sağlığının en önemli konularından biri olup hem sıklığı hem de sakatlık ve ölüm başta olmak üzere ciddi sağlık sorunlarına yol açan sonuçları nedeniyle önemli bir halk sağlı̆̆ı sorunudur. ${ }^{2}$ Her yıl çok sayıda çalışan iş kazaları nedeniyle yaşamını yitirmekte veya sürekli ya da geçici olarak iş göremez duruma gelmektedir. International Labour Organization (ILO) verilerine göre yılda 2.78 milyon ölümle sonuçlanan, 374 milyon ölümle sonuçlanmayan işle ilgili yaralanma ve hastalık var; bunların birçoğu işten sürekli devamsızlıklara neden olmaktadir. ${ }^{3}$ World Health Organization (WHO)'a göre Avrupa Bölgesi’ndeki toplam hastalık yükünün \%1,6’sı sağlıksız çalışma koşullarına bağlı ve işle ilişkili hastalık yükünü oluşturan karsinojenler, havada asılı partiküller, ergonomik zararlar ve gürültü gibi majör risklerin içinde en büyük pay \%40,0 ile iş kazalarına bağlı yaralanmalardır. ${ }^{4}$ Türkiye'de ise 2016 yılında 286.086 iş kazası meydana gelmiş bu kazalar sonucunda 1405 çalışan hayatını kaybetmiştir. $^{5}$

İnşaat işkolu, istihdam alanı en büyük ve en tehlikeli işkollarından birisi ve sadece ülkemizde değil Dünya'da da hem işçi sayısında hem de meydana gelen iş kazalarında ön sıralarda yer almaktadır. ILO verilerine göre inşaat işçileri, diğer sektörlerde çalışan işçilere oranla 3-6 kat daha fazla kazaya uğrama riski taşımakta, oldukça yüksek sayılarda iş kazası yaşanmaktadır., ${ }^{3,6-7}$ Tüm dünyada inşaat sektöründe her yıl 60.000 ölümcül kaza yaşanmakta ve her 10 dakikada bir kişi iş kazası sonucu yaşamını yitirmektedir. ${ }^{3}$ Ülkemizde ise Sosyal Güvenlik Kurumu (SGK) 2016 yılı verilerine göre 44,552 iş kazasının meydana geldiği ve 496 işçinin de yaşamını yitirdiği, tüm iş kazalarının \% 15’i, ölümlü iş kazalarının \% 35'i inşaat sektöründe meydana gelmektedir. ${ }^{5}$ Ülkemizde inşaat sektörü madencilik, ulaşım ve makine/metal sektörleriyle birlikte iş kazasının en sık yaşandığı sektörlerden birisidir. ${ }^{5}$ Özellikle ülkemizdeki inşaat faaliyetlerinin asıl işveren alt işveren ilişkisi bağla- mında yürütülmesi ve inşaat alanlarında birden fazla firma ve işveren olması sebebiyle iş sağlı̆̆ ve güvenliği(İSG) tedbirlerinin alınması, bu tedbirlerin uygulanması ve denetlenmesi güçleşmektedir. Buna ek olarak işverenler tarafından İSG’ye yönelik faaliyetlerin gereksiz ekonomik yük olarak görülmesi ve çalışanların bu konudaki bilinçsizlikleri ve eğitimsizlikleri iş yerlerinde yaşanan kazala-rın temel sebeplerindendir. ${ }^{8}$

Genellikle iş kazalarının \%80'inin insanlara, \%18'inin fizik ve mekanik çevre koşullarına bağlı olarak meydana gelmesi \%98'inin önleyici tedbirlerin alınabileceğini göstermektedir. İş kazalarının bireysel ve toplumsal olarak verdiği zararlardan dolayı bu tedbirlerin alınması ertelenmemesi gereken bir durumdur., ${ }^{9,10}$

Bu çalışmanın amacı; Adana'da bir inşaat firmasında çalışanların iş kazası geçirme durumları ile çalışma koşulları ve ilişkili etmenlerin araştırılmasıdır.

\section{GEREÇ ve YÖNTEMLER}

Araştırmamız kesitsel tipte bir çalışma olup Haziran-Aralık 2017 tarihinde yapıldı. Araştırmanın evrenini Adana'da bir inşaat firmasının iki ayrı şantiyesindeki tüm çalışanlar oluşturmaktadır. Çalışmaya başladığımız tarihte 256 bir şantiyede, 150 diğer şantiyede olmak üzere toplam 406 çalışan bulunmaktaydı. Birinci şantiyede 202 çalışan, ikinci şantiyede 124 çalışan olmak üzere toplamda 326 çalışana literatürden hazırlanan anket uyguland1., ${ }^{511-15}$ Ulaşmayı planladığımız çalışan sayısının \%83,3'üne anket yapıldı. Şantiyede çalışanların 17'si anket uygulandığı esnada devam etmek istemediğini söylediği için yarım kalan anketler çalışmaya dâhil edilmedi. Çalışmanın evreninden 15 kişiye ön anket çalışması yapıldı ve bunlar verilere dâhil edilmedi. Çalışanlardan 48 kişi çalışmaya katılmayı kabul etmedi. Çalışmanın amacına yönelik olarak hazırlanan 49 soruluk Kişisel Bilgi Formu ve İş ve İş Kazası Bilgi Formu gerekli izinler alındıktan sonra araştırmaya katılmayı kabul eden çalışanlara araştırmacı tarafından yüz yüze görüşme yöntemi ile uygulandı. Anket yapılmadan önce katılımcı- 
lara 'Bilgilendirilmiş onam formu' imzalatıldı. İstatistiksel analiz için "Statistical Package for the Social Sciences-SPSS 20 for Windows" paket programı kullanıldı. Tanımlayıcı istatistiksel yöntemlerle ortalama, yüzdelik dağılım ve standart sapma değerleri hesaplandı. Çalışanların iş kazası geçirme durumları ile sosyodemografik özellikler ve işle ilgili özelliklerine göre anlamlı fark gösterip göstermedikleri ki kare testi ile analizi edildi. $\mathrm{p}<0,05$ istatistiksel olarak anlamlı kabul edildi. Bu çalışma için Çukurova Üniversitesi Tip Fakültesi Etik Kurulundan 14.04.2017 tarihli 63 sayılı ve çalışmayı yaptığımız inşaat firmasının yetkilisinden izin alındı.

\section{BULGULAR}

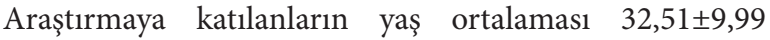
(min:18, max:61) olup, \%46,62'si 30 yaş altı grubundadır. Katılımciların \%96,93'ü erkek, \%61,65'i evli, \%61,96'sı ilköğretim mezunu idi. Katılımcıların \%49,50'si asgari ücret (2017 yılına göre) ve altında ve altı gelir düzeyine sahipti (Tablo 1).

\begin{tabular}{|c|c|c|c|}
\hline & & $\mathrm{N}$ & $\%^{*}$ \\
\hline Yaş & \multicolumn{3}{|c|}{ ort: $32,51 \pm 9,99(\min : 18, \max : 61)$} \\
\hline \multirow{2}{*}{ Cinsiyet } & Kadın & 10 & 3,07 \\
\hline & Erkek & 316 & 96,93 \\
\hline \multirow{3}{*}{$\begin{array}{l}\text { Medeni } \\
\text { Durum }\end{array}$} & Evli & 201 & 61,66 \\
\hline & Bekar & 118 & 36,20 \\
\hline & Boşanmış/Eși Ölmüş & 7 & 2,14 \\
\hline \multirow{4}{*}{$\begin{array}{l}\text { Eğitim } \\
\text { Durumu }\end{array}$} & $\begin{array}{l}\text { Okuryazar değil- } \\
\text { Okuryazar }\end{array}$ & 23 & 7,06 \\
\hline & İlköğretim & 202 & 61,96 \\
\hline & Lise & 62 & 19,02 \\
\hline & Üniversite & 39 & 11,96 \\
\hline \multirow{3}{*}{$\begin{array}{l}\text { Gelir } \\
\text { Düzeyi } \\
(\mathrm{n}=319)\end{array}$} & $\leq 1404^{*}$ & 158 & 49,50 \\
\hline & $1404<$ & 161 & 50,50 \\
\hline & \multicolumn{3}{|c|}{ ort: $2043,14 \pm 1121,10(\min : 1200, \max : 10000)$} \\
\hline Toplam & & 326 & 100 \\
\hline
\end{tabular}

Çalışanlardan 7 kişi aldıkları ücretle ilgili net bir bilgi vermedi. Katılımcların \%61,35’i aylık gelirinin kendisi ve ailesinin ihtiyaçlarını karşılamaya yetmediğini belirtti. Katılımcıların \%48,77’si şantiyede kalmaktadır. Katılımcıların \%50,92'sinin bakmakla yükümlü olduğu kişi sayısı 4 ve üzerindedir. Katılımcıların \%49,39’u sigarayı ,\%6,75’i alkolü düzenli kullanmaktadır. Çalışanların \%5,52'sinin kronik bir hastalığı var, \%3,68'i ise düzenli ilaç kullanmaktadir.

Araştırmamızda çalışanların meslekte toplam çalışma süreleri ortalaması 14,71 $\pm 9,91$ yll (min:1 ay, max: 47 yl), $\% 40,80$ ' inin çalışma süresi 16 yıl ve üzeri, çalışmaya başlama yaşı ortalama 17,02 $\pm 4,25, \% 23,31$ 'inin çalışmaya başlama yaşı 14 yaş ve altıdır (Tablo 2).

\begin{tabular}{|c|c|c|c|}
\hline & & $\mathrm{n}$ & $\%$ \\
\hline \multirow{4}{*}{$\begin{array}{l}\text { Meslekte Toplam } \\
\text { Çalışma Süresi }\end{array}$} & $\leq 5 \mathrm{yll}$ & 70 & 21,47 \\
\hline & $6-10 \mathrm{yll}$ & 59 & 18,10 \\
\hline & $11-15 \mathrm{yll}$ & 64 & 19,63 \\
\hline & $16 \leq$ & 133 & 40,80 \\
\hline \multirow{3}{*}{ Çalışmaya Başlama Yaşı } & $\leq 14$ & 76 & 23,31 \\
\hline & $15-17$ & 100 & 30,68 \\
\hline & $18 \leq$ & 150 & 46,01 \\
\hline \multirow{3}{*}{ Çalışılan Alan } & Mavi Yakalı & 282 & 86,50 \\
\hline & Beyaz Yakalı & 13 & 3,99 \\
\hline & Diğer & 31 & 9,51 \\
\hline \multirow{3}{*}{$\begin{array}{l}\text { Şu an Çalıştığı Yerdeki } \\
\text { Çalışma Süresi(ay) }\end{array}$} & $0-3$ & 78 & 23,93 \\
\hline & $4-6$ & 122 & 37,42 \\
\hline & $7 \leq$ & 126 & 38,65 \\
\hline \multirow{2}{*}{ Haftalık Çalışma Saati } & $\leq 45$ saat & 9 & 2,76 \\
\hline & $45<$ & 317 & 97,24 \\
\hline \multicolumn{2}{|l|}{ Ek İş Yapma Durumu } & 49 & 15,03 \\
\hline \multirow{3}{*}{ İşten Memnuniyet Durumu } & Memnun Değil & 76 & 23,31 \\
\hline & Kararsız & 77 & 23,62 \\
\hline & Memnun & 173 & 53,07 \\
\hline \multirow{3}{*}{$\begin{array}{l}\text { Çalışma Saatinden Mem- } \\
\text { nuniyet }\end{array}$} & Memnun Değil & 127 & 38,96 \\
\hline & Kararsız & 67 & 20,55 \\
\hline & Memnun & 132 & 40,49 \\
\hline \multicolumn{2}{|l|}{ İşini Monoton Bulma Durumu } & 159 & 48,77 \\
\hline \multicolumn{2}{|l|}{ İşini İsteyerek Seçme Durumu } & 219 & 67,18 \\
\hline \multicolumn{2}{|c|}{ İşinin Stresli Olduğunu Düşünme Durumu } & 232 & 71,17 \\
\hline \multicolumn{2}{|c|}{ İşinin Sağlığına Zarar Verdiğini Düşünme Durumu } & 172 & 52,76 \\
\hline
\end{tabular}


Katılımcıların \%86,50'si mavi yakalılar grubundadır. Katılımcıların şu anki çalışılan yerlerindeki görev süreleri or-

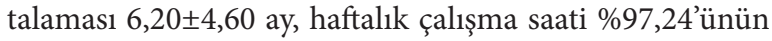
45 saat üzeri olarak belirlendi. Katılımcıların \%15,03’ü ek iş yaptığını belirtti. Katılımcıların \%23,31'i çalıştıkları işten, \%38,95'i çalışma saatinden memnun olmadıklarını, \%48,77’si işini monoton bulduğunu belirtti. Katılımc1ların \%67,18’i işini isteyerek tercih etmişti. Çalışanların \%71,17’si işinin stresli olduğunu, \%52,76’sı işinin sağlığına zarar verdiğini düşünmekteydi. (Tablo 2) Katılımcıların çalıştıkları işi tercih nedenleri sor-gulandığında ilk sırada sosyal güvenlik olurken $(\% 50,31)$; en az tercih nedeni iş güvenliği, işçi sağ-lığı(\%12,27) idi. İşinin stresli olduğunu düşünen kişilerin stres kaynağı sorulduğunda ise ilk sırada çalışma koşullarını kötü olması $(\% 43,10)$ vardı. Katılımcıların \%60,74'ü mesleki eğitim almadığını, \%24,85'i çalışma hayatı boyunca; \%28,83'ü ise bu işe başlarken İSG eğitimi almadığını söyledi. Katılımcılara İSG kurallarına uymama ana nedeni sorulduğunda en fazla eğitimsizlik (\%64,72) cevabı verilmiştir.

Katılımcıların \%5,21'i bu işyerinde, \%16,87'si çalışma hayatı boyunca iş kazası geçirmiş, \%10,43'ü ramak kala olay yaşadığını belirtti. İş kazası nedeni sorgulandığında ilk sırada $(\% 41,18)$ kişilerin düşmesi gelmektedir. Katılımcılardan \%52,94'ü kaza sonucu hastaneye sevk edildiğini, \%70,59’u iş günü kaybı olduğunu beyan etti. Bunların yarısının iş günü kaybı 7 gün üzeriydi. (Tablo 3)

İş kazası geçiren katılımcıların iş kazasının meydana geldiği gün, mevsim ve saat ilk sırada Pazar, kış mevsimi, işin ilk 2 saatinde meydana geldiğini söyledi. İş kazası geçirenlerin iş kazası geçirme nedeni olarak ilk sırada dikkatsizlik $(\% 52,94)$ olduğu beyan edildi. Katılımcıların yaptığı işin iş kazası açısından riski sorulduğunda \%45,40'1 yüksek, \%21,17'si ise düşük olarak değerlendirdi. İş yerinde kaza önleme uygulamaları yeterliliği sorgulandığında \%40,80'i yetersiz olduğunu belirtti. 'Size göre iş kazalarının önlenmesi için ne yapılmalı?' sorusuna \%39,57'si kurallara uyanlara ve iş kazası geçirmeyenlere ödül verilmesi, \%38,04'ü kişisel koruyucu malzemeler düzenli kullanılmalı şeklinde cevap verdi. Çalışanların tehlikeli durum ve davranışlara uygulanmasını önerdikleri yaptırımlara \%71,20’si uyarı cevabı verdi. Katılımcılar 'sizce kişisel koruyucu donanım (KKD) kullanmak gerekli mi?' sorusuna \%86,20'si gerekli olduğunu, \%71,17'si KKD kullandığını belirtti. KKD kullanmayanların \%86,17'si rahatsız ettiğini, \%58,51'i işini aksattığını beyan etti.

\begin{tabular}{|c|c|c|c|}
\hline \multicolumn{2}{|c|}{$\begin{array}{l}\text { İş Kazası Geçirme Durumu ve Geçirilen İş Kazasının } \\
\text { Özellikleri }\end{array}$} & $\mathrm{N}$ & $\%$ \\
\hline \multicolumn{2}{|l|}{ İş Kazası Geçirme Durumu } & 17 & 5,21 \\
\hline \multirow{3}{*}{ Geçirilen İş Kazasının Türü } & Kişilerin Düşmesi & 7 & 41,18 \\
\hline & $\begin{array}{l}\text { Kesici/Delici Alet } \\
\text { Yaralanması }\end{array}$ & 6 & 35,29 \\
\hline & $\begin{array}{l}\text { Düşen Cisimlerin } \\
\text { Çarpması }\end{array}$ & 4 & 23,53 \\
\hline \multirow{3}{*}{ Geçirilen İş Kazasını Sonucu } & $\begin{array}{l}\text { Hastaneye Sevk } \\
\text { Edilme }\end{array}$ & 9 & 52,94 \\
\hline & Ayakta Tedavi & 4 & 23,53 \\
\hline & Tedavi Görmedim & 4 & 23,53 \\
\hline \multicolumn{2}{|l|}{ İş Günü Kaybı } & 12 & 70,59 \\
\hline \multirow{2}{*}{ İş günü kaybı } & 0-7 gün & 6 & 50 \\
\hline & 7 gün üzeri & 6 & 50 \\
\hline
\end{tabular}

Katılımcıların bu iş yerinde kaza geçirme durumuna göre bağımsız değişkenler karşılaştırıldığında sigara içme durumu hariç istatistiksel olarak anlamlı bir fark tespit edilmedi. Sigara içenlerin iş kazası geçirme oranı daha yüksekti (p=0,022).(Tablo 4) İş kazası ve çalışma koşulları arasında anlamlı bir ilişki yoktu. 
Sakarya Tip Dergisi 2019;9(4):661-668

ATEȘ ve Ark., İs Kazasıı ve Çalıșma Koșulları ile İlișkisi

Tablo 4.Çalışmaya katılanların genel özelliklerine göre şu anki işyerinde iş kazası düzeyleri

\begin{tabular}{|c|c|c|c|c|c|c|c|c|}
\hline & & \multicolumn{2}{|c|}{ İş Kazası(+) } & \multicolumn{2}{|c|}{ İş Kazası(-) } & \multicolumn{2}{|c|}{ Toplam } & \multirow{2}{*}{$\mathrm{p}$ değeri } \\
\hline & & $\mathrm{n}$ & $\%^{*}$ & $\mathrm{n}$ & $\%^{*}$ & $\mathrm{~N}$ & $\%^{* *}$ & \\
\hline \multirow{3}{*}{ Yaş Dağılımı } & $<30$ & 9 & 5,92 & 143 & 94,08 & 152 & 46,62 & \multirow{3}{*}{0,711} \\
\hline & $30-39$ & 5 & 5,56 & 85 & 94,44 & 90 & 27,61 & \\
\hline & $40 \leq$ & 3 & 3,57 & 81 & 96,43 & 84 & 25,77 & \\
\hline \multirow{2}{*}{$\begin{array}{l}\text { Medeni } \\
\text { Durum }\end{array}$} & Evli & 10 & 4,98 & 191 & 95,02 & 201 & 61,66 & \multirow{2}{*}{0,496} \\
\hline & Bekar & 7 & 5,60 & 118 & 94,40 & 125 & 38,44 & \\
\hline \multirow{3}{*}{$\begin{array}{l}\text { Öğrenim } \\
\text { Duru- } \\
\operatorname{mu}(n=303)\end{array}$} & İlköğretim & 14 & 6,93 & 188 & 93,07 & 202 & 66,67 & \multirow{3}{*}{0,201} \\
\hline & Lise & 1 & 1,61 & 61 & 98,39 & 62 & 20,46 & \\
\hline & Üniversite & 2 & 5,13 & 37 & 94,87 & 39 & 12,87 & \\
\hline \multirow{2}{*}{$\begin{array}{l}\text { Sigara } \\
\text { kullanma } \\
\text { durumu }\end{array}$} & Evet & 14 & 7,61 & 170 & 92,39 & 184 & 56,44 & \multirow{2}{*}{$0,022^{\star * *}$} \\
\hline & Hayır & 3 & 2,11 & 139 & 97,89 & 142 & 43,56 & \\
\hline \multirow{2}{*}{$\begin{array}{l}\text { Alkol kullan- } \\
\text { ma durumu }\end{array}$} & Evet & 4 & 8,33 & 44 & 91,67 & 48 & 14,72 & \multirow{2}{*}{0,230} \\
\hline & Hayır & 13 & 4,68 & 265 & 95,32 & 278 & 85,28 & \\
\hline
\end{tabular}

Tablo 5. İș kazası geçiren çalışanların çalıșma yaşamı özelliklerine göre iș kazası düzeyleri

\begin{tabular}{|c|c|c|c|c|c|c|c|c|}
\hline & & \multicolumn{2}{|c|}{ İş Kazası(+) } & \multicolumn{2}{|c|}{ İş Kazası(-) } & \multicolumn{2}{|c|}{ Toplam } & \multirow{2}{*}{$\mathrm{p}$ değeri } \\
\hline & & $\mathrm{n}$ & $\%^{*}$ & $\mathrm{n}$ & $\%^{*}$ & $\mathrm{~N}$ & $\%^{* *}$ & \\
\hline \multirow{4}{*}{$\begin{array}{l}\text { Meslekte } \\
\text { Toplam } \\
\text { Çalışma } \\
\text { Süresi }\end{array}$} & $\leq 5$ yil & 5 & 7,14 & 65 & 92,86 & 70 & 21,47 & \multirow{4}{*}{0,754} \\
\hline & $6-10$ yil & 2 & 3,39 & 57 & 96,61 & 59 & 18,10 & \\
\hline & $11-15 \mathrm{yll}$ & 4 & 6,25 & 60 & 93,75 & 64 & 19,63 & \\
\hline & $16 \leq$ & 6 & 4,51 & 127 & 95,49 & 133 & 40,80 & \\
\hline \multirow{2}{*}{$\begin{array}{l}\text { Çalışılan } \\
\text { Alan(n=313) }\end{array}$} & Mavi Yakalı & 15 & 5,32 & 267 & 94,68 & 282 & 90,10 & \multirow{2}{*}{0,475} \\
\hline & Diğer & 2 & 6,45 & 29 & 93,55 & 31 & 9,90 & \\
\hline \multirow{3}{*}{$\begin{array}{l}\text { Şu an } \\
\text { Çalıştığı } \\
\text { Yerdeki } \\
\text { Çalışma } \\
\text { Süresi(ay) }\end{array}$} & $0-3$ & 4 & 5,13 & 74 & 94,87 & 78 & 23,93 & \multirow{3}{*}{0,384} \\
\hline & $4-6$ & 4 & 3,28 & 118 & 96,72 & 122 & 37,42 & \\
\hline & $7 \leq$ & 9 & 7,14 & 117 & 92,86 & 126 & 38,65 & \\
\hline \multirow{2}{*}{$\begin{array}{l}\text { Haftalık } \\
\text { Çalışma } \\
\text { Saati }\end{array}$} & $\leq 45$ saat & 0 & 0,00 & 9 & 100,00 & 9 & 2,76 & \multirow{2}{*}{0,614} \\
\hline & $45<$ & 17 & 5,36 & 300 & 94,64 & 317 & 97,24 & \\
\hline \multirow{2}{*}{$\begin{array}{l}\text { Ek İş Yapma } \\
\text { Durumu }\end{array}$} & Evet & 4 & 8,16 & 45 & 91,84 & 49 & 15,03 & \multirow{2}{*}{0,242} \\
\hline & Hayır & 13 & 4,69 & 264 & 95,31 & 277 & 84,97 & \\
\hline
\end{tabular}

\section{TARTIŞMA}

Çalışmamızda katılımcıların \%5,2'i bu iş yerinde, $\% 16,8^{\prime}$ 'si çalışma hayatı boyunca iş kazası geçirmiş, \%10,4'ü bu iş yerinde ramak kala olay yaşamıştı. SGK verilerine göre Türkiye'de iş kazası sıklık hızı $\% 1,78$ ve tüm iş kazalarının $\% 15$ 'i; ölümlü iş kazalarının \%35'i inşaat sektöründe mey- dana gelmektedir. ${ }^{5} \quad$ Ylldız ve Yılmaz’ın yaptığı çalışmada $\% 10$ 'u hayatı boyunca en az bir iş kazası yaşamış, \%15'i ise mevcut işyerinde iş kazasına veya ramak kala olayına maruz kalmıştır. ${ }^{16}$ Çalışmamızda çalışanların küçük yaralanmaları iş kazası olarak beyan etmemelerinden oranlar olduğundan düşük bulunmuş olabilir. 
Araştırmamızda çalışanlardan sigara içenlerin \%7,6, sigara içmeyenleri de \% 2,1'i iş kazası geçirmiş olup, iki grup arasındaki fark istatistiksel olarak anlamlı bulunmuştur. Gemi söküm işyerinde yapılan bir araştırmada sigara kullanımı ile iş kazası geçirme durumu arasında anlamlı bir fark yoktu. ${ }^{17}$ Etiyopya'da inşaat işçilerine yapılan bir çalışmada sigara kullanımı ile mesleki yaralanma arasında anlamlı bir ilişki bulunmamıştır. ${ }^{18}$ Yine inşaat alanında yapılmış bir çalışmada, sigara içenlerin sigara içmeyenlere göre daha fazla mesleki yaralanma riski olduğu bulunmuştur. ${ }^{19}$ Çalışmamızda sigara içme durumuyla iş kazası arasında anlamlı ilişki bulunmasında çalışma esnasında sigara içilmesi dikkat dağınıklı̆̆ına neden olabileceğinden ya da çalışma dışında içilmesi ise daha fazla mola vermeleri gerekeceğinden her moladan sonra işe adaptasyon sorunu yaşayabilirler. Sigara kullanımı dikkat dağınıklığı, konsantrasyonu düşürme gibi fiziksel ve ruhsal problemlerle iş kazalarına sebep olmaktadır.

Çalışmamızda katılımcıların iş kazası türü sorulduğunda ilk sırada \%47,2 ile kişilerin düşmesi olmuştur. Yapılan çalışmalarda genellikle iş kazası nedeni olarak yüksekten düşme ilk sırada ve bu tür kazalar genelde ölümle sonuçlanmaktadır. ${ }^{20,21}$ Yüksekten düşme en çok çalışanların bireysel özellikleri, saha koşulları, organizasyonel özellikler, ekipmanlar (iskeleler/merdivenler) ve hava koşullarından kaynaklanmaktadir. ${ }^{22}$

Araştırmamızda katılımcılardan iş kazası geçirenlerin \%52,9'u hastaneye sevk edilmiş, \%70,6'sının iş günü kaybı olmuş, bunlarında \%50'si 7 gün üzeri iş günü kaybı oldugunu belirtmiştir. Yapılan bir çalışmada saptanmış olan iş kazalarının \%77'si iş günü kaybı gerçekleşmeyen kazalardır. ${ }^{2}$ Mersha, Mereta ve Dube'nin inşaat sektöründe yaptı̆̆ı çalışmasında mesleki yaralanmaların \%10,8'i hastaneye yatırılmış, \%13,4'ünün 7 gün ve üzeri iş günü kaybı olmuş. ${ }^{13}$ Çalışmamızda bu çalışmalardan farklı olarak hastaneye sevk ve iş günü kaybının fazla olmasının nedeni olarak çalışanların büyük yaralanmaları iş kazası olarak algılamaları olduğu düşünülmektedir.
Çalışmamızda iş kazaları en fazla Pazar günü, kış mevsimi ve işin ilk 2 saatinde meydana gelmişti. İspanya inşaat sektörü iş kazalarını inceleyen bir çalışmada, en fazla kazanın olduğu gün pazartesi olarak gözlendi. ${ }^{23}$ Yapılan bir çalışmada ölümle sonuçlanan iş kazalarının haftanın Pazartesi gününde daha sık, kazaların neredeyse yarısının sabah saatlerinde ve çoğunun yaz ayında meydana geldiği ortaya çıkmıştır. ${ }^{24}$ İş kazalarının daha çok Pazartesi ve Pazar günleri gerçekleşmesinin nedeni haftanın ilk günü ve son günlerinde, sabah saatlerinde çalışanların konsantrasyonlarının düşük olmasından, hafta sonu yaklaştıkça işçilerin dikkatinin dağılması ve biriken yorgunluktan dolayı iş kazalarının bugünlerde arttığı söylenebilir.

Çalışmamızda bu iş yerinde iş kazası geçirenlerin \%53'ü iş kazası geçirme nedeni olarak ilk sırada dikkatsizlik cevabını vermişlerdir. Bayraktaroğlu, Aras ve Atay'ın çalışmasında daha önce iş kazası geçirmiş katılımcıların \%40'1 dalgınlık, dikkatsizlik, uykusuzluk, yorgunluk veya hastalıktan dolayı iş kazası geçirmişlerdir. ${ }^{25}$ İşçilerin dikkatsiz davranışlarının iş kazası sebebi olarak yüksek oranda çıkması çalışanların içinde bulundukları psikolojik durum ve işe adapte olmanın iş kazaları açısından önemli olduğunu ve insan faktörünün iş kazalarında önemli olduğunu göstermektedir.

\section{SONUÇ ve ÖNERİLER}

Çalışmamızda katılımcıların \%5,2'i bu iş yerinde,\%16,8'si çalışma hayatı boyunca iş kazası geçirmişti. İş kazası türü en sık kişilerin düşmesi idi. Çalışmamızda iş kazaları en fazla Pazar günü, kış mevsimi ve işin ilk 2 saatinde meydana gelmişti. Sigara içenlerde iş kazası anlamlı olarak yüksek bulundu.

İş kazalarını önlemek için iş yoğunluğunun fazla olduğu ve hava şartlarını kötü olduğu kış ve yaz aylarında iş sağlığı ve güvenliği uygulamalarına daha fazla özen gösterilmesi ve denetlenmesi gerekmektedir. Haftanın ilk ve son günleri ve günün ilk saatlerinde yapılan işleri daha az konsantrasyon gereken işlerle değiştirmek, iş yoğunluğunu azaltmak 
ve iş güvenliği uygulamalarının her zaman sıkı denetlenmesi gerekmektedir. Kaza nedeni olarak dikkatsizliğin ilk sırada olması çalışanların iş yoğunluğu nedeniyle dinlenmeleri ve molalarının kısıtlı olması gibi nedenlerle dikkatsiz davranmaması için mola sürelerinin daha verimli ve uzun tutulması gerekmektedir. Düşme nedenli kazaların daha fazla olması iskele, güvenlik kemeri gibi koruyucularını kullanılmadığını ve denetim eksikliğini göstermekte ve buna yönelik işs sağlığı ve güvenliği denetimlerinin arttırılması gerekmektedir. Yüksekten düşme şeklindeki kazaları önlemek için çalışanlar kişisel koruyucu donanımlarını eksiksiz olarak kullanması ve özellikle emniyet kemeri ve can halatına daha da dikkat etmesi, işveren; korkuluk, uyarıcı ve dikkat çekici tedbirleri almak konusunda daha hassas olması gerekmektedir. Çalışmamızda iş kazası geçirenlerle geçirmeyenler karşılaştırıldığında sigara içme durumu ile anlamlı bulundu. Bu nedenle çalışanlar iş esnasında sigara içmemesi için uyarılmalı ve sigara bağımlılığına yönelik çalışanlara eğitim verilmelidir. 
Sakarya Tip Dergisi 2019;9(4):661-668

ATEȘ ve Ark., İș Kazası ve Çalışma Koșulları ile İlișkisi

\section{Kaynaklar}

1. http:// www.iloencyclopaedia.org (Erişim Tarihi:03.02.2017).

2. Duman E, Hamzaoğlu O. İstanbul'da Bir Șantiyede Çalșanların İș Kazalarının İzlemi. Türk Tabipleri Birliği Mesleki Sağllk ve Güvenlik Dergisi 2011;11(40):35-42.

3. ILO(International Labour Office). http://www.ilo.org/global/topics/safety-and-health-atwork/lang--en/index.htm. (Erişim Tarihi:03.02.2017)

4. http://www.euro.who.int/en/what-we-do/health-topcs/enviironmental-health/occuparionalhealth/ facts- and- figures ( Erişim Tarihi:03.02.2017).

5. http://www.sgk.gov.tr/wps/portal/sgk/tr/kurumsal/istatistik/sgk_istatistik_yilliklari (Erișim Tari-hi. 03.09.2017).

6. Eurostat, "European Statistics on Accidents At Work (ESAW), http://ec.europa.eu/eurostat/ statisticsexplained/index.php/Accidents_at_work_statistics, (ET: 23.01.2018).

7. http://laborsta.ilo.org. (Erişim Tarihi: 11.02.2017)

8. Yağımlı M, Hacıbektasoğlu SE. Türkiye'de İnsaat Sektöründe Yasanan İs Kazaları ve Ölümlü I̦ș Kazast Sayılarınin Tahmini. Gümüşhane Üniversitesi Sosyal Bilimler Enstitüsü Elektronik Dergisi 2018;22:142-156.

9. Cankurt M. İș Yeri Çalıșma Sistemi ve İşyeri Fiziksel Faktörlerin İș Kazaları Üzerindeki Etki-leri. TUHİ İs Hukuku ve İktisat Dergisi 2007;6(20):1.

10. Perry MJ, Sun BX, Zhang HX, Wang X, Christiani D. Emergency Department Surveillance of Occupational Injuries in Shanghai's Putuo District, People's Republic of China. Ann Epidemiol 2005; 15:351-357.

11. Dembe AE, Erickson JB, Delbos RG, Banks SM. The impact of overtime and long work hours on occupational injuries and illnesses: new evidence from the United States. Occup Environ Med 2005;62:588-597.

12. Yllmaz F, Tan O. Bir İnşaat Șantiyesinde İș Kazalarının Neden Olduğu İs Günü Kayıpla-rının İșverene Maliyetinin Belirlenmesi. International Journal of Economic and Administrati-ve Studies 2015;7(14):143-156.

13. Mersha H, Mereta ST, Dube L. Prevalence of occupational injuries and associated factors among construction workers in Addis Ababa, Ethiopia. Journal of Public Health and Epi-demiology 2017;9(1):1-8
14. Gülmez H, Çalşanların Yaşam Kalitesini Etkileyen Faktörler. Turkish Journal of Family Medicine and Primary Care 2013;7(4):74-82.

15. Polat B, Polat A. İnșaat Sektöründe Doğu Anadolu Bölgesi için İș Güvenliği Koşullarının Incelenmesi. Int. J. Pure Appl. Sci. 2017;3(1):24-32.

16. Ylldız S, Yllmaz M. Türk İnşaat Sektöründe Çalışanların Güvenlik Kültürü Düzeyinin ve Güvenlik Performanst ile İliskisinin İncelenmesi. Politeknik Dergisi 2017;20(1):137-149.

17. Ünal NB. Gemi Geri Dönüşüm Teknikleri. İș Sağlğ̆ı ve Güvenliği Dergisi 2011;49:28-32.

18. Adane MM, Gelaye KA, Beyera GK, Sharma HR, Yalew WW. Occupational Injuries Among Building Construction Workers in Gondar City, Ethiopia. Occupational Medici-ne®Health Affairs 2013;1:5.

19. Chau N, Mur JM, Benamghar L, Siegfried C, Dangelzer JL, Francais M, Jacquin R, Sourdot A. Relationships between certain individual characteristics and occupational injuries for va-rious jobs in the construction industry: a case-control study. Am J Ind Med. 2004;45:84-

20. Uğur M. İnșaat Sektörümüzdeki Bașlıca I̦ș Kazası Tipleri. Türkiye Mühendislik Haberleri Dergisi 2011;469:32-39.

21. Hinze J, Devenport J, Giang G. Analysis of Construction Worker Injuries That Do Not Result in Lost Time. Journal of Construction Engineering and Management 2006;132(3):321327.

22. Nadhim EA, Hon C, Xia B, Stewart I, Fang D. Falls from Height in the Construction In dustry: A Critical Review of the Scientific Literature. Int. J. Environ. Res. Public Health 2016;13:638.

23. Lopez M, Ritzel D, Fontaneda I, Alcantera G. Construction Industry Accidents in Spain, Journal of Safety Research 2008;39: 497-507.

24. Baradan S, Akboğa Ö, Çetinkaya U, Usmen MA. Ege Bölgesindeki İnșaat I̦ș Kazalarının Siklık ve Çapraz Tablolama Analizleri. IMO Teknik Dergi 2016; 27(131):7345-7370.

25. Bayraktaroğlu S, Aras M, Atay E. Çalıșanlarda İş Güvenliği ve İș Kazası Algısı: Mavi Yaka-lllar Üzerine Bir Araștırma. Uluslararası Yönetim ve Sosyal Araștırmalar Dergisi 2018, $5(9): 1-15$ 